\title{
Cell Adhesion Molecule 1
}

National Cancer Institute

\section{Source}

National Cancer Institute. Cell Adhesion Molecule 1. NCI Thesaurus. Code C106272.

Cell adhesion molecule 1 (442 aa, $\sim 49 \mathrm{kDa}$ ) is encoded by the human CADM1 gene. This protein plays a role in calcium-dependent cell-cell adhesion. 